\title{
OPPORTUNITIES OF E-LEARNING AT UNIVERSITIES IN UKRAINE IN THE OPINION OF TEACHERS (ACCORDING TO EMPIRICAL SOCIOLOGICAL RESEARCH)
}

\section{Khyzhniak L. M.}

\section{INTRODUCTION}

With the development of e-learning, a special segment of the educational market - the market of e-learning services - is being formed, since there are both demand and supply of these services. Learning service is specific economic benefits provided to an individual (or a group) to meet a variety of educational needs as well as the product of collaborative work of teachers and students, which increases intellectual opportunities of the individual. The learning service should have benefits that can satisfy the consumers' needs related to obtaining the qualifications. Learning services meet personal (end-user), collaborative (enterprise-employer) and public (state, society) needs. Scientists classify learning services according to the ways of financing: as a public good, the production of which is financed by the state, and as a private good, the demand for which is determined by the existing purchasing power of users and the behaviors of families of applicants.

Learning services as a product of educational activity are the result of the implementation of a variety of activities (pedagogical, scientific, organizational and managerial) by educators to meet the educational needs of individuals and the society as a whole. Learning services belong to the group of creability products. These are products for which the buyer cannot establish the volume and quality or it involves very high costs. Due to the ambiguity of the learning services quality, there is an asymmetry of information between the seller and the buyer of services as for their quality; the development of the service coincides with the process of its consumption and is an integral part in time and spatial aspects (the exception is distance learning); learning service is not unified as a product; educational establishments sell their learning services at a price lower than costs when demand grows, subsidizing their consumers; services are not permanent. 
Materials of the empirical sociological study with contributions from the author can focus on the following tasks:

1. To define the commercial apeal of e-learning services entry into a market for Ukrainian universities according to expert evaluations.

2. To research estimates of demand in the labor market for specialists who have received electronic higher education according to expert evaluations.

3. To identify the potential target audience of e-learning at universities in Ukraine according to expert evaluations.

Basic concepts. Analysis of studies of the correlation between the educational market and the labor market allows us to focus on such aspects of the topic.

Firstly, in the modern world, against the background of the interconnection and interdependence of education, the labor market and the social behavior of individuals and groups, there is a tendency towards a gap between the sphere of education and the labor market. Scientists attribute this gap to a change in the "landscape of employment," with the capital of flexibility and mobility of representatives of the most soughtafter professions ${ }^{1}$.

Secondly, the educational services market and the labor market are beginning to link a new phenomenon - the recognition by scholars and practitioners of the need for lifelong education. Therefore, in conditions of flexible employment, the role of an individual's motivation to both receive quality education and continue it increases. As a result, attempts are being made to technologize the process of forming a positive motivation to learn from potential and real students in social and cognitive activity. The factors that determine the motivational positions of students most often include "the inability to plan their time well; excessive study load; not quite satisfactory quality of teaching in a number of disciplines, etc."2.

Thirdly, the introduction of electronic education is becoming a factor in the competitiveness of the university. Competitiveness indexes are

1 Попова Е. С. Горизонтальная профессиональная мобильность, профессиональное образование и рынок труда в России в динамике лет. Социологическая наука и сочиальная практика. 2018. № 1. С. 53-70.

2 Жукоцкая А. В., Васильев И. А. Мотивационные позиции студенческой молодёжи на образовательном поле. Вестник Института сочииологии. 2018. № 25. C. 78-99. 
gaining popularity, in which, in our opinion, the time has come to include e-education adoption indicators at universities ${ }^{3}$. The level of social competitiveness is capable of supporting and even enhancing an individual who, on the one hand, is motivated for continuous education, and on the other, can realize this motivational aspiration in the most accessible form, including in the form of electronic educational service. Trends in international higher education favor the dependence of an increasing number of universities (even highly rated) on foreign students. This situation leads to higher costs for universities to attract and train them due to the high competition in the educational market ${ }^{4}$. Since modern foreign students are representatives of the "digital generation", it is advisable for universities to offer them electronic educational programs.

Fourthly, globalization contributes to the development of the world labor market and the world market of educational services. Some researchers are calling on universities to stimulate the export of educational services, as it is today a trend in the development of the global market for educational services ${ }^{5}$. Sharing this point of view, we add the following: the export opportunities of e-education are enormous if their use is based on the real resources of the university and is supported by effective management in a particular university. Under these conditions, information about specific educational programs becomes more important, and not about the university as a whole ${ }^{6}$.

Fifth, research shows that the most individualized communications gradually crowd out direct interpersonal communication, which, of

${ }^{3}$ Немировский В. Г., Немировская А. В. Социальная конкурентоспособность: шансы на успех у молодежи и взрослых. Социологический журнал. 2018. № 2. C. 135-149.

4 Кемп. Нил. Новые тенденции международного рынка образования. Международное высшее образование. 2016. № 85. C. 19-21. https://ihe.hse.ru/article/ view/2941/2678.

5 Айдрус И. А., Горшкова Л. Ю. Особенности развития мирового рынка образовательных услуг на современном этапе. М. : Рос. ун-т дружбы народов, 2015. $320 \mathrm{c}$.

${ }^{6}$ Шэтток Майкл. Повышение информированности участников рынка: Рамочная программа улучшения качества преподавания (TEF) в британском высшем образовании. Международное высшее образование. 2018. № 92. С. 27-29. https://ihe.hse.ru/article/view/7564/8386. (accessed 10.05/2019). 
course, creates certain social risks ${ }^{7}$. At the same time, it is the electronic educational service that can best meet the educational needs of a particular student and correspond to his lifestyle. Individualization of education through the provision of electronic educational services by the university does not require the unity of place, time and action. This creates a special comfort in obtaining a university education.

The characteristic of e-university education is universality. Michael Barber, Katelyn Donnelly, Saad Rizvi offered modern universities several positioning options: an elite university; mass university; university occupying a certain niche; local university; lifelong university ${ }^{8}$. However, all the types of universities noted above may lose their competitiveness in a digital society if they do not focus on e-education (and not only on the use of its individual elements). E-education allows students to combine study and work. Sociological studies show that students are increasingly considered employment as a basis for their professional careers while at university ${ }^{9}$.

The foregoing trends in education and the modern labor market allows us to propose the formation of a theoretical framework for a sociological study of the potential of e-university education, which is based on two triads, namely, behavioral and individualizational, which manifests itself in all societies that indulge in an individualized culture (Fig. 1-2).

The first triad includes the interconnection and interdependence of the market for electronic educational services, the labor market and the social behavior of individuals and groups.

The second triad includes the interrelation of individualization of educational communications, the individualization of education through the consumption of electronic educational services, the individualization of employment through individual trajectories of search and work performance. At the same time, individualization of employment is especially relevant among freelancers.

${ }^{7}$ Каргаполов С. В., Каргаполова Е. В. Электронные средства коммуникации в социальных практиках современной молодежи (по материалам конкретного социологического исследования). Социологический альманах. Вып. 7. Минск : Беларуская навука, 2016. С. 275.

8 Барбер М., Доннелли К., Ризви С. Накануне схода лавины. Высшее образование и грядущая революция. Вопросы образования. 2013. № 3. С. 158.

9 Филоненко В. И., Скачкова Л. С., Филоненко Ю. В. Занятость студентов во время обучения в вузе. Социологические исследования. 2018. № 9. С. 135-140. 
The market of electronic educational services

Social behavior of

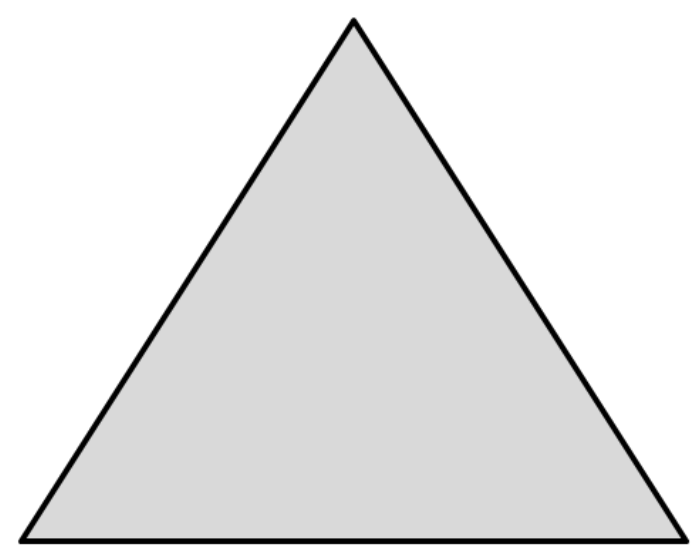

individuals and groups

Labor market

Fig. 1. Behavioral triad in e-university education

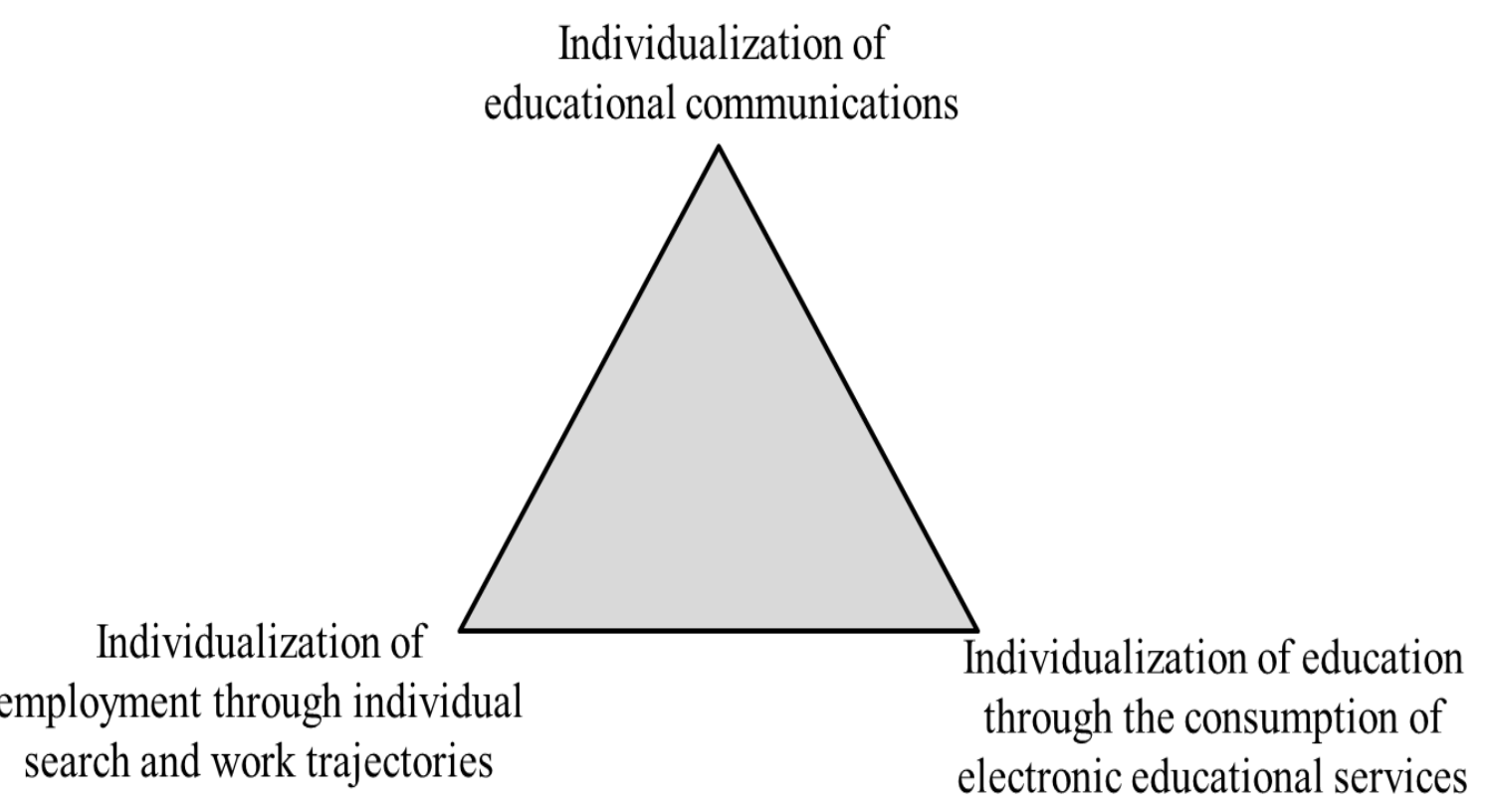

Fig 2. The triad of individualization in e-university education

Research methods. Referring to the analysis of empirical sociological research material that the authors conducted involving the employees of the Department of Applied Sociology and Social Communications of V. N. Karazin Kharkiv National University within 
the research theme "Problems of introducing the technologies of e-learning in Ukrainian Higher School" (from 10 to October 25, 2016 the survey conducted including 260 lecturers-experts from 42 universities concerning the problems of e-learning technologies implementing in higher education of Ukraine). Criteria for experts' selection: they work in higher educational institutions of Ukraine, use electronic learning technologies in their professional activities, use electronic learning technologies in higher educational institutions where an expert works.

For our purpose the opportunities of e-learning at universities can be divided into two groups: 1) market (commercial) and 2) non-market (reputational) ones.

\section{Commercial Appeal for Entry of Ukrainian Universities into the Market of E-Learning Services According to Expert Evaluations}

Among the performance indicators of a modern university, scientists lay emphasis on the demand for a specialist trained by a particular university in the labor market ${ }^{10}$.

As for e-learning, its demand depends on whether it is commercially successful or not. The commercialization of educational activities of universities governs this demand, makes us to provide educational services with the help of e-learning technologies, taking into account the commercial component. Expert views as for commercial success of elearning in Ukraine is divided: $46 \%$ respondents think it is possible, approximately $19 \%$ do not agree with it, and $35 \%$ couldn't pick a side at the time of sociological survey (fig. 3).

Social, status and demographic characteristics of experts do not influence such evaluations. They can also signify the underdevelopment of the market for e-learning services in Ukraine.

More than two third of experts $(68 \%)$ consider that the implementation of e-technologies in the educational process is a necessary condition to improve their competitive positions (fig. 4).

${ }^{10}$ Ильчук С. Б. Востребованность выпускника на рынке труда как индикатор эффективной деятельности современного вуза. Журнал соииологии и социальной антропологии. 2008. Т. 11. № 1. С. 191-200. 


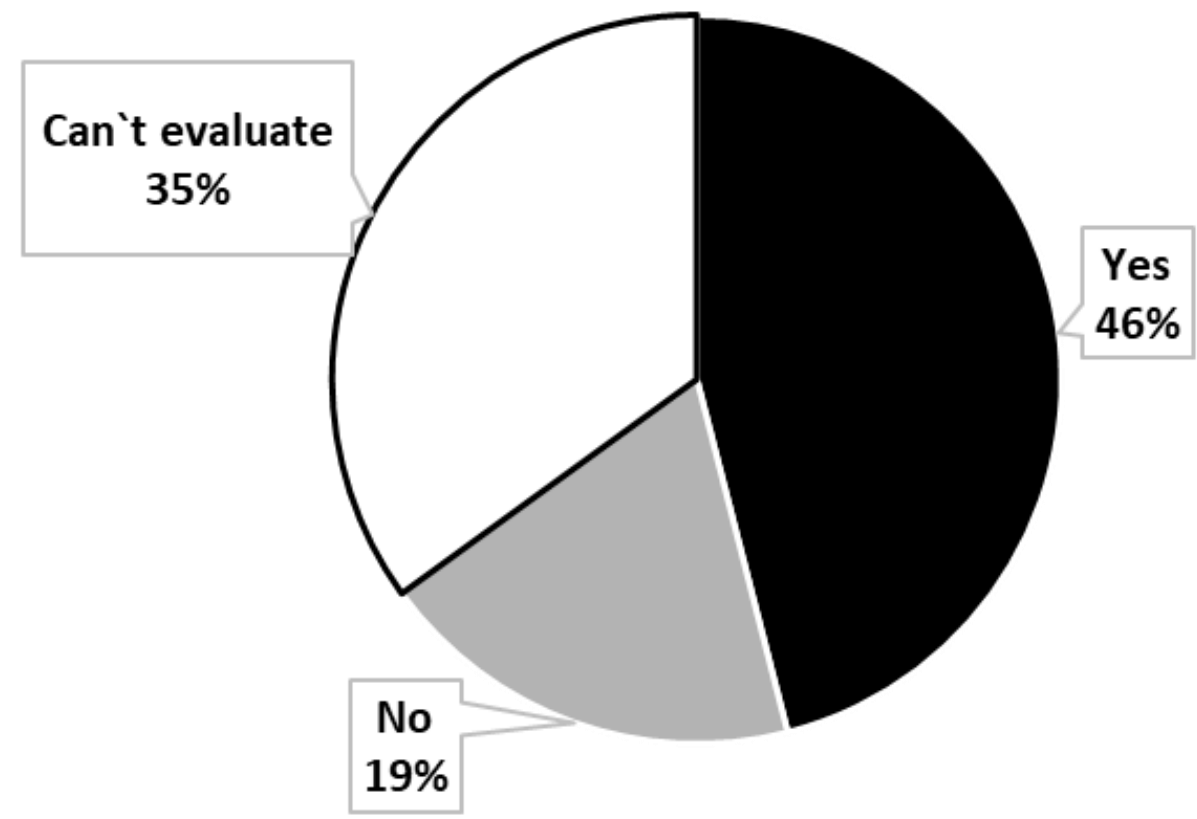

Fig. 3. Can e-learning at universities in Ukraine be commercially successful (\% for respondents; expert evaluation, $n=260$ )

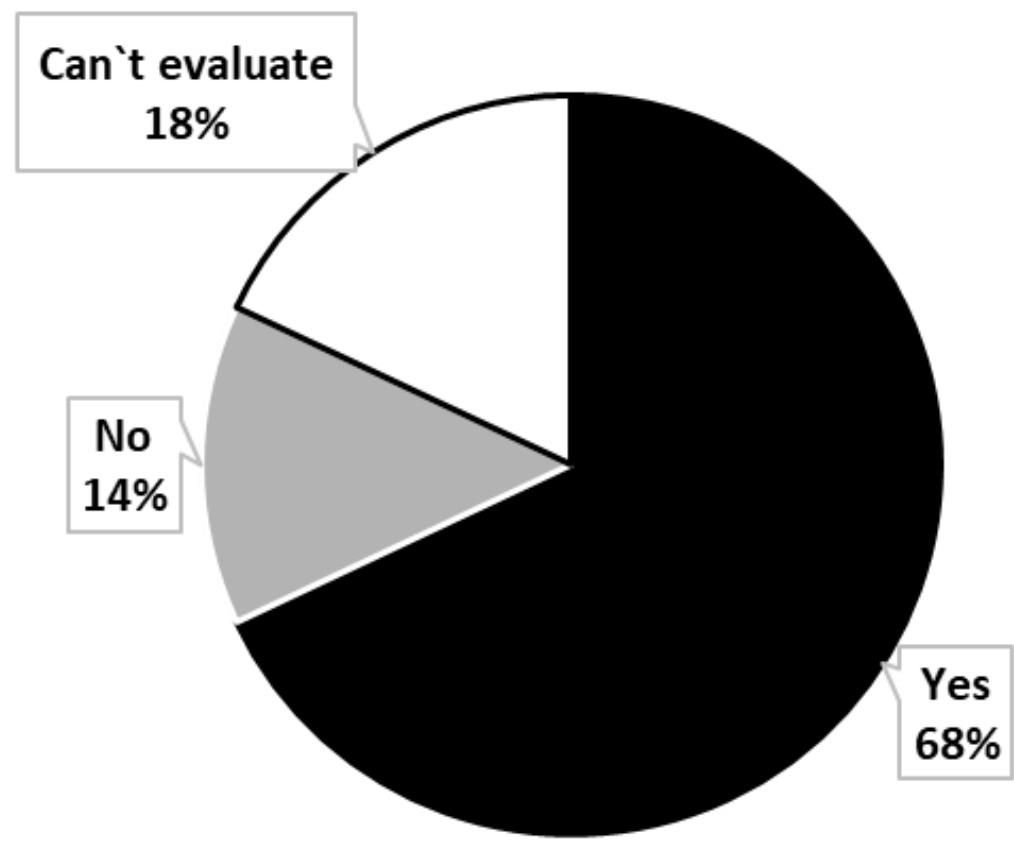

Fig. 4. Do you agree with the statement "Universities which do not develop e-learning technologies cannot compete in the market of learning service?" (\% for respondents; expert evaluation, $n=260$ ) 
Experience has shown that the benefit of learning services, including electronic ones, does not start immediately, it depends not only on the direct quality of the services received, but also on a number of parameters that the university practically cannot influence (such as the activity of the graduate when job hunting, his/her communication skills and labor market conditions).

Nowadays, the need for social technologies how to overcome the risks of e-education is being mainstreamed in Ukraine. Mostly, scientists are suggested to form students' critical thinking and develop their own views and ability to communicate effectively; come to creative solutions and anticipate situations. The vision of their role and place in the modern world in interdependence with others is also very important ${ }^{11}$. "The analysis of expert assessments indicates that alternative models of higher education presented in the form of a dichotomy "traditional education - e-learning" does not receive support from the lecturers as subjects of the educational process. The mixed model of higher education becomes attractive for them. This problem is the result of the selection of a traditional model and the introducing e-learning technologies in the system of higher education. Higher school functioning in the conditions of educational hybrids is a new reality of Ukrainian higher educational establishments"12. Researchers record an increase in the distance between the two main educational communities - students and lecturers ${ }^{13}$.

As part of the study the experts were asked to answer the open question: "In your opinion, which risks are possible for subjects of e-learning?". The most common answers of the expert are given below.

\section{Risks of switching to e-learning for students:}

- loss of quality of education, especially if there are no effective forms of control;

11 Трякіна О. О. Електронне навчання (e-learning): нові тенденції розвитку в процесі самоосвіти. Вісник Луганського нац. ун-ту імені Т. Г. Шевченка. Луганськ, 2011. № 5 (216). C. 25-34.

12 Хижняк Л. М., Хижняк К. В. Гібридизація у вищій освіті в умовах впровадження технологій електронного навчання. Соціальні технологї̈: актуальні проблеми теорії та практики. 2016. Вип. 72. С. 144.

13 Зборовский Г. Е. Можно ли быть вместе, находясь врозь: студенты и преподаватели в вузе. Социологические исследования. 2018. № 9. C. 49-58. DOI: $10.31857 / \mathrm{S} 013216250001958-6$. 
- loss of opportunities to socialize in a student group due to constant interpersonal contacts between students;

- absence of emotional contact with the tutor;

- loss of opportunities to acquire experience in team work and ability to build relationships in real time and space;

- at the initial stage of the e-learning development at university, it is possible to "collect" certificates without proper quality;

- "fragmentarity" of knowledge gained through the e-learning technology;

- students can not complete their studies without self-discipline.

Risks of switching to e-learning for teachers.

- difficulties to master new teaching methods and technologies;

- growth of competitiveness among educators;

- increase in the intensity of teaching work and additional workload;

- reduction of the need for educators and as a consequence - the risk to lose the job (even for highly qualified teachers);

- absence of emotional contact with students.

Risks for switching to e-learning for universities:

- reduction in educational process effectiveness and quality of education;

- inconsistency of teacher training with requirements for e-teaching;

- admission risks;

- increased costs (at least at the initial stage) for educational process material and technical support;

- risk to lose some effective teachers who won't be able to adjust for new requirements;

- financial and reputational loses (at least at the initial stage) as a result of lack of experience in e-learning;

- reduction in educational process effectiveness and quality of education because of conventional attitude of both students and teachers to the educational process;

- problems with qualitative assessment of educational outcome;

- loss (or reduction) of effectiveness of pedagogic function of universities. 


\section{Labor market demand forecast for specialists who got e-education at universities, according to expert evaluation}

To set down in plat the development of e-learning service market, we suggested the experts to assess its immediate prospects, namely to answer the question: "In your opinion, how will the demand for specialists who have received e-education at university change in the labor market in Ukraine in the next 2-3 years?». Again the opinions of the experts were different. Here are the opinions of groups of experts for specialists who have received e-education at university:

1) Experts who believe that the demand will increase $-19 \%$.

2) Experts who believe that the demand will not change $-41 \%$.

3) Experts who believe that the demand will decrease $-5 \%$.

4) Experts who cannot pick a side - $35 \%$ (fig. 5).

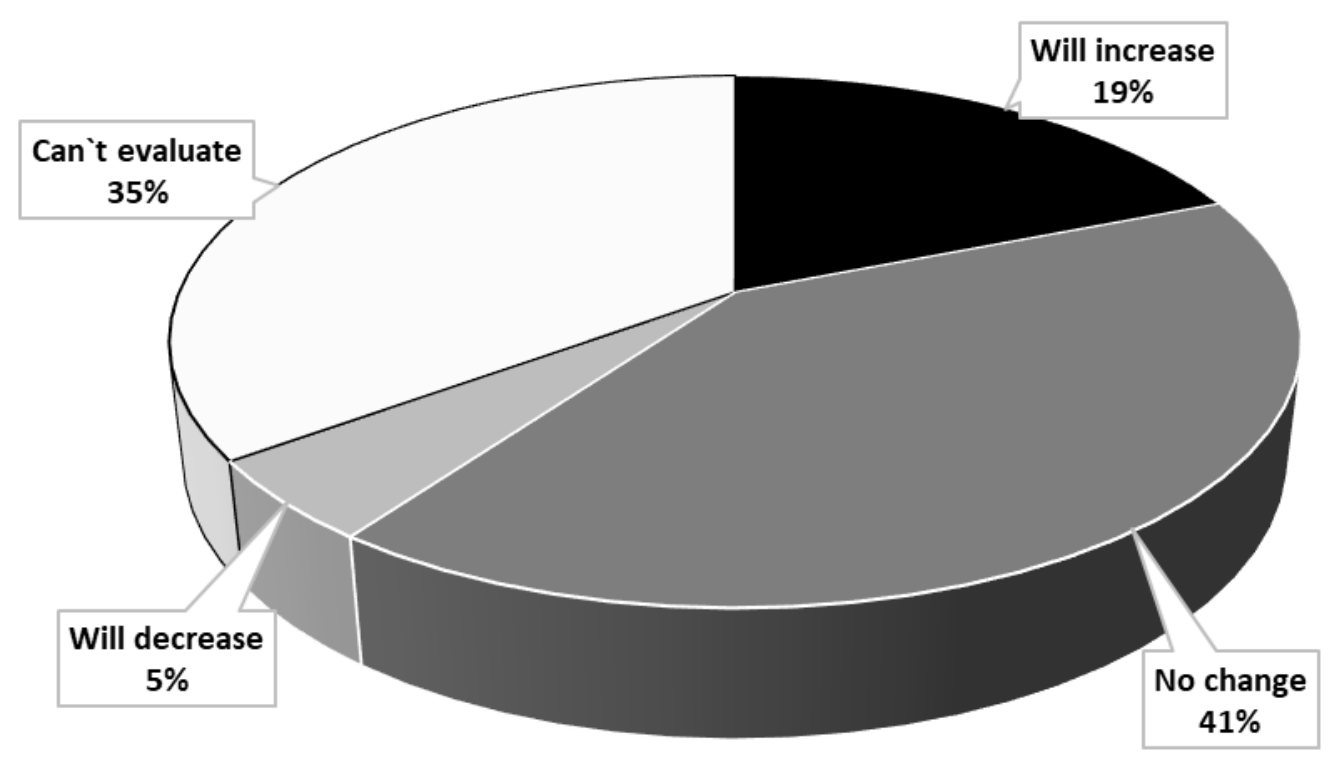

Fig. 5. How will the demand for specialists who have received eeducation at university change in the labor market in Ukraine in the next 2-3 years? (\% for respondents; expert evaluation, $n=260$ )

A statistically significant correlation between the experts' estimations concerning the demand for specialists with electronic higher education depending on the specialization of the respondents is given in the table 1 (Cramer's coefficient is equal to 0.235 at $1 \%$ level of 
significance). Experts in the field of natural sciences are more optimistic (table 1).

\section{Table 1}

\section{Experts' Estimations Concerning the Demand for Specialists with Electronic Higher Education Depending on the Specialization}

(\% for respondents; $n=260$ )

\begin{tabular}{|l|c|c|c|c|}
\hline \multirow{2}{*}{ Expert groups } & \multicolumn{3}{|c|}{ Specialization of the experts } \\
\cline { 2 - 5 } & $\begin{array}{c}\text { Engineering } \\
\text { sciences }\end{array}$ & $\begin{array}{c}\text { Natural } \\
\text { sciences }\end{array}$ & $\begin{array}{c}\text { Social and } \\
\text { Humanity } \\
\text { sciences }\end{array}$ & Economics \\
\hline $\begin{array}{l}\text { Experts who } \\
\text { believe that the } \\
\text { demand will } \\
\text { increase }\end{array}$ & 13 & 39 & 16 & 17 \\
\hline $\begin{array}{l}\text { Experts who } \\
\text { believe that the } \\
\text { demand will not } \\
\text { change }\end{array}$ & 36 & 31 & 49 & 28 \\
\hline $\begin{array}{l}\text { Experts who } \\
\text { believe that the } \\
\text { demand will } \\
\text { decrease }\end{array}$ & $\mathbf{2 1}$ & $\mathbf{8}$ & $\mathbf{1}$ & $\mathbf{5}$ \\
\hline $\begin{array}{l}\text { Experts who cannot } \\
\text { pick a side }\end{array}$ & $\mathbf{3 1}$ & $\mathbf{2 2}$ & $\mathbf{3 4}$ & $\mathbf{5 0}$ \\
\hline
\end{tabular}

Electronic educational services fit organically into the digital economy, which requires special competencies from staff and increases risks in education and in the labor market. Therefore, it is important that students and lecturers adapt to the uncertainty of the university environment that arose during the transition to a digital economy ${ }^{14}$. One of the effective ways of such an adaptation, as studies show, is the ability of students to find employment during the period of study at the university. Ability to employment is considered by scholars as a

14 Мозговая А. В. Адаптация молодёжи к неопределённости университетской среды в период модернизации института высшего образования. Социологическая наука и соччиальная практика. 2018. № 2. С. 110-125. DOI: https://doi.org/ 10.19181/snsp.2018.6.2.5860. 
competence that provides employment and career prospects of the individual, competitiveness in the labor market $^{15}$.

\section{Target audience of e-learning at universities in Ukraine according to experts' evaluations}

E-learning is a way to solve the problem of non-uniform access to educational resources with the help of modern e-learning tools. Scientists point out a lot of advantages of e-learning, including independence from geographic location; time saving; efficiency and psychological comfort. In this case, e-learning technologies should be developed and implemented taking into account the requirements of consumers of e-learning services.

To forecast the development of e-learning service market and the labor market of the relevant professionals, it is important to identify target groups which are interested in e-learning. An expert survey showed that there are three groups which are the leaders of the target audience in the e-learning, namely: individuals who want to combine learning with production activities (67\%); people who are geographically isolated from their educational resources $(58 \%)$; people with physical, physiological or emotional problems (55\%). Experts expect a slight increase in the demand for e-learning services for those who want to change their profession or improve their skills (43\%) and those who already have substantial knowledge and want to take the educational program over a short period of time (39\%), or wish to master special educational programs consisting of courses provided by different educational establishments (37\%). Thus, according to experts, academic mobility cannot be the dominant factor in increasing the demand for e-learning services (fig. 6).

According to experts, the least demand for e-learning services should be expected from those who are engaged in arts, sports and do not want to interrupt education (9\%) and those who have not completed university education in their youth $(8 \%)$. In our opinion, this situation is due to the fact that the prestige of university education in contemporary Ukraine is not high, that is why people of the middle age and elderly people who do not have it, are not motivated to continue their education.

15 Мозговая А. В., Яишников А. Ю. Способность к трудоустройству как ресурс профессиональной адаптации личности. Вестник Института соџиологии. 2018. № 26. С. 143-157. 


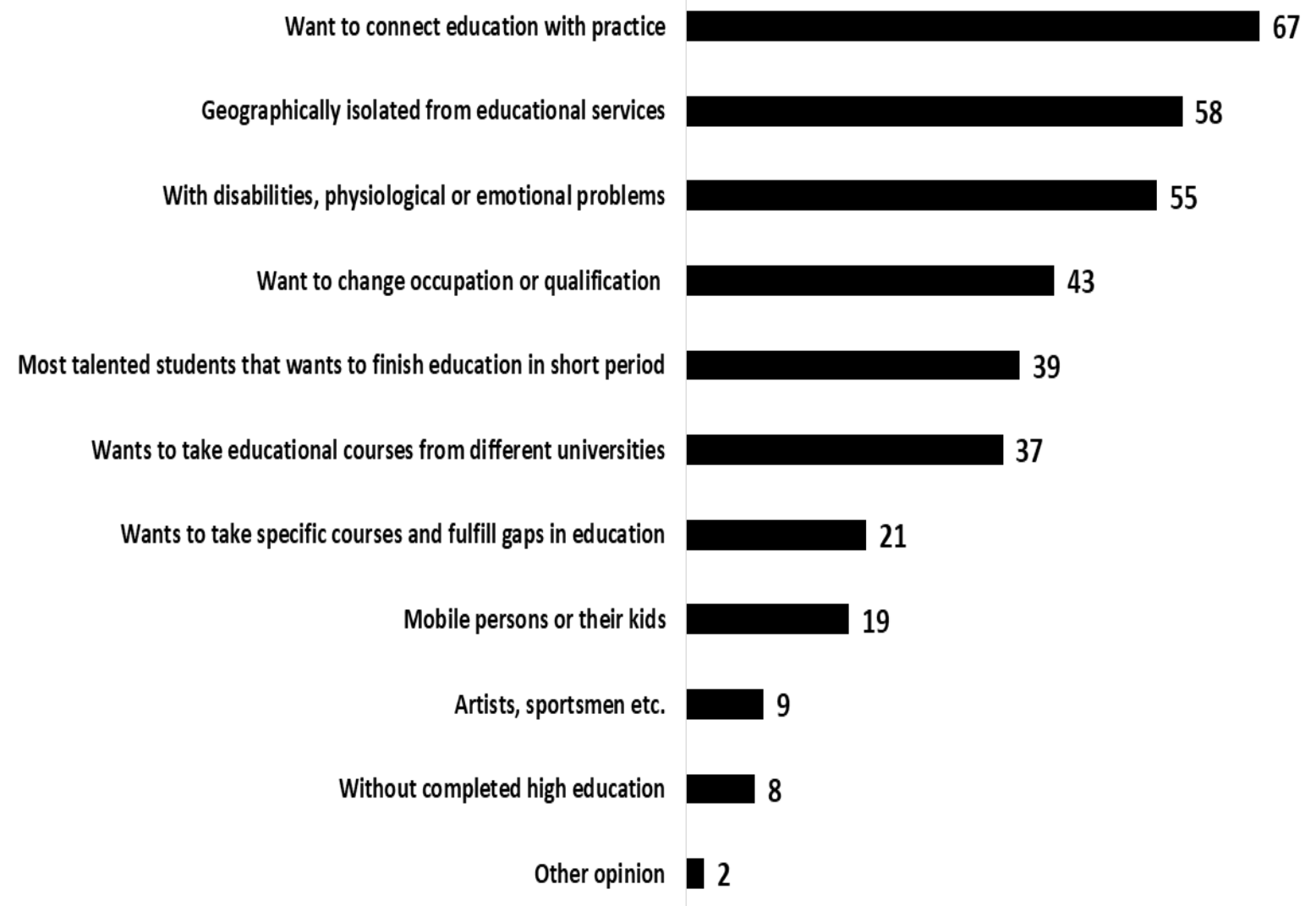

Fig. 6. Target audience for e-learning at universities in Ukraine (expert evaluation in \%, $n=260$ )

Universities that seek to be successful and meet the challenges of the contemporaneity should research not only the demand for e-learning services, but also create this demand with the help of appropriate communication technologies (advertising and PR), identify the categories of people who, in their social status, educational needs and professional interests require new forms of learning services, which include first of all e-learning.

Prisonmates or ex-prisonmates who serve or have served the time in jail can be a bright example of such specific target audience. This is a specific group, which include those who have had such experience and need social reintegration after dispensation from imprisonment. Educational opportunities play a prominent role for reintegrating a person into society in modern conditions.

A lot of ex-prisoners are actively searching for work, planning to take up individual labour activity, create their own enterprise, get education, but those who are passive stand cannot be disregarded either, as they are at risk population group. These individuals especially need attention from both the 
employees of rehabilitation centers and the state institutions that take care of this contingent, including employment services, where they go to seek employment. The employment services could become the customers of corresponding e-learning programs for such individuals and implement educational programs together with different educational establishments of different levels. In this case, e-learning is relevant (on conditions that target audience is computerate, which can also be the task of rehabilitation centers and employment services).

Let us sum up. First, people released from places of detention may be considered as potential target audience for e-learning; secondly, it is expedient for educational institutions of different levels to develop special educational programs for this group which would meet the needs, interests, target orientation and values of this rather heterogeneous group. The obtained results show that among those who were released from prison there are a lot of people who have active plans, primarily related to economic activity (job hunting, setting up their own business, obtaining education). Therefore, in our opinion, it is very important to develop a set of actions to prevent the negative attitude towards such women, especially on the part of employers and educators, overcome stereotypes and prejudices, etc., which will facilitate successful professional reintegration of this contingent into the community, and reduce backslide of female crime. Finally, a society is interested in social reintegration of its citizens, and for this purpose it should take care of their education. E-learning, due to its characteristics, becomes a factor that allows the representatives of this group of women to raise (renew) their social status.

Foreign students may also be potential target audiences of e-learning in Ukrainian universities. However, in this case the issues of organization of effective intercultural communication by the university become actual $^{16}$. To substantiate this conclusion, we should add the following. We share opinion that at present, socio-cultural modernization plays a much more important role in the renovation of modern university education strategy than strategies based on economic principles"17.

16 Бакіров В. С., Ушакова Н. І., Хижняк Л. М. Міжкультурна комунікація в університеті: історичний досвід і виклики сучасності. Вісник Харківського національного університету імені В. Н. Каразіна. Серія «Соціологічні дослідження сучасного суспільства: методологія, теорія, методи». 2017. Вип. 39. С. 286-293.

17 Богданова М. В. Этос университета: социологическая операционализация потенциала «неписаных правил». Социологический журнал. 2017. № 2. С. 153. 
The labor market enter students, which for one reason or another leave universities. For many of them, e-learning services can serve as the instrument for the professional growth and acquisition of the educational status of a person with higher education ${ }^{18}$.

\section{CONCLUSIONS}

The concept of education which is suggested by B. Clark and which we totally agree with, is based on the idea of support for university changes ${ }^{19}$. Let us add that these changes come in contact with commercial and non-commercial elements of education. It fully relates to the opportunities of e-learning in modern Ukraine.

The market (commercial) potential of e-education determines the commercial attractiveness (success) of e-education, which is evidenced, first of all, by the demand of specialists who have received e-education in the labor market. The nonmarket (reputation) potential of e-education determines the image characteristics of the university providing e-learning services.

The analysis of the ratio of commercial and non-commercial attractiveness for the universities of Ukraine to enter the market of e-learning services shows: the reputational advantages of the Ukrainian universities for entry in the e-learning service market, according to experts, now dominate a bit commercial advantages.

The potential target audience of e-learning in Ukraine is rather heterogeneous. Scientists distinguish the corporate and educational sectors and consumers of individual e-learning. Work with different groups of consumers of e-learning services involves the development of relevant educational programs by each specific university.

We have proposed to consider the ratio of the market of electronic educational services and the labor market in terms of the individualization of modern culture as a triad that includes the individualization of social communications (including educational), the individualization of education through the consumption of electronic educational services and the individualization of employment.

${ }^{18}$ Горбунова Е. В. Выбытия студентов из вузов: исследования в России и США. Bопросы образования. 2018. № 1. С. 110-131.

${ }^{19}$ Кларк Б. Р. Поддержание изменений в университетах. Преемственность кейсстади и концепций; пер. с англ. М. : НИУ ВШЭ, 2011. 312 с. 
E-education can give universities reputational and economic (financial, commercial) benefits if they have a special intellectual resource - a motivational one. It is, on the one hand, about the motivation of students to receive high-quality electronic educational services, and on the other hand, the motivation and willingness of lecturers to provide such a service as necessary. A separate factor is the readiness of universities for e-education, which requires separate consideration.

Research of employers opinions regarding the professional and personal qualities of graduates, as well as employers' preferences in the process of recruiting young professionals appear more often ${ }^{20}$. At a later stage it is expedient to expand the circle of experts on the development of e-learning service market and labor market at the expense of employers and representatives of potential target audience of these markets.

\section{SUMMARY}

The article is devoted to the disclosure of the potential of e-university education in Ukraine as assessed by teachers. The author has conditionally divided the potential of e-university education into two groups: 1) market (commercial) and 2) non-market (reputation). The theoretical framework of sociological study of the potential of university education is proposed, which is based on two triads, which include behavioral and individualized characteristics. The conclusions are based on the materials of an empirical sociological study conducted with the participation of the author. The article outlines the commercial attractiveness for Ukrainian universities to enter the market of electronic educational services in experts' assessments. The demand forecast on the labor market for specialists who have received electronic higher education in experts' assessments has been estimated. The potential target audience of e-university education in Ukraine in experts' assessments has been defined.

\section{REFERENCES}

1. Айдрус И. А., Горшкова Л. Ю. Особенности развития мирового рынка образовательных услуг на современном этапе. М. : Рос. ун-т дружбы народов, 2015. 320 с.

${ }^{20}$ Месхи Б. Ч., Филоненко В. И., Скачкова Л. С., Филоненко Ю. В. Проблемы и парадоксы трудоустройства студенческой молодежи в оценках работодателей (по итогам социологического исследования). Власть. 2017. № 10. С. 83-90. 
2. Бакіров В. С., Ушакова Н. І., Хижняк Л. М. Міжкультурна комунікація в університеті: історичний досвід і виклики сучасності. Вісник Харківського національного університету імені В. Н. Каразіна. Серія "Сочіологічні дослідження сучасного суспільства: методологія, теорія, методи». 2017. Вип. 39. С. 286-293.

3. Барбер М., Доннелли К., Ризви С. Накануне схода лавины. Высшее образование и грядущая революция. Вопросы образования. 2013. № 3. C. 152-236.

4. Богданова М. В. Этос университета: социологическая операционализация потенциала «неписаных правил». Социологический журнал. 2017. № 2. С. 153-170.

5. Горбунова Е. В. Выбытия студентов из вузов: исследования в России и США. Bonросы образования. 2018. № 1. С. 110-131.

6. Жукоцкая А. В., Васильев И. А. Мотивационные позиции студенческой молодёжи на образовательном поле. Вестник Института социологии. 2018. № 25. С. 78-99.

7. Зборовский Г. Е. Можно ли быть вместе, находясь врозь: студенты и преподаватели в вузе. Соииологические исследования. 2018. № 9. С. 49-58.

8. Ильчук С. Б. Востребованность выпускника на рынке труда как индикатор эффективной деятельности современного вуза. Журнал соџиологии и социильной антропологии. 2008. Т. 11. № 1. C. 191-200.

9. Каргаполов С. В., Каргаполова Е. В. Электронные средства коммуникации в социальных практиках современной молодежи (по материалам конкретного социологического исследования). Социологический альманах. Вып. 7. Минск : Беларуская навука, 2016. C. 271-276.

10. Кемп. Нил. Новые тенденции международного рынка образования. Международное высшее образование. 2016. № 85. C. 19-21. https://ihe.hse.ru/article/view/2941/2678 (accessed 10.05/2019).

11. Кларк Б. Р. Поддержание изменений в университетах. Преемственность кейс-стади и концепций. М. : НИУ ВШЭ, 2011. 312 с.

12. Месхи Б. Ч., Филоненко В. И., Скачкова Л. С., Филоненко Ю. В. Проблемы и парадоксы трудоустройства студенческой молодежи в оценках работодателей (по итогам социологического исследования). Власть. 2017. № 10. С. 83-90. 
13. Мозговая А. В. Адаптация молодёжи к неопределённости университетской среды в период модернизации института высшего образования. Социологическая наука и соичиальная практика. 2018. № 2. С. 110-125.

14. Мозговая А. В., Яишников А. Ю. Способность к трудоустройству как ресурс профессиональной адаптации личности. Вестник Института соичологии. 2018. № 26. С. 143-157.

15. Немировский В. Г., Немировская А. В. Социальная конкурентоспособность: шансы на успех у молодежи и взрослых. Социологический журнал. 2018. № 2. 135-149.

16. Попова Е. С. Горизонтальная профессиональная мобильность, профессиональное образование и рынок труда в России в динамике лет. Социологическая наука и сочииальная практика. 2018. № 1 . С. 53-70.

17. Трякіна О. О. Електронне навчання (e-learning): нові тенденції розвитку в процесі самоосвіти. Вісник Луганського нац. ун-ту імені Т. Г. Шевченка. Луганськ, 2011. № 5 (216). С. 25-34.

18. Филоненко В. И., Скачкова Л. С., Филоненко Ю. В. Занятость студентов во время обучения в вузе. Социологические исследования. 2018. № 9. С. 135-140.

19. Хижняк Л. М., Хижняк К. В. Гібридизація у вищій освіті в умовах впровадження технологій електронного навчання. Соціальні технології: актуальні проблеми теорії та практики. 2016. Вип. 72. C. 137-144.

20. Шэтток Майкл. Повышение информированности участников рынка: Рамочная программа улучшения качества преподавания (TEF) в британском высшем образовании. Международное высшее образование. 2018. № 92. C. 27-29. https://ihe.hse.ru/article/view/ 7564/8386 (accessed 10.05/2019).

\section{Information about the author: Khyzhniak L. M.}

Doctor of Sociological Sciences, Professor, Professor of the Applied Sociology and Social Communication Department, School of Sociology,

V. N. Karazin Kharkiv National University 4, maidan Svobody, Kharkiv, 61045, Ukraine 